\title{
Immunoexpression of cell cycle biomarkers in neuroblastoma samples and its correlation with prognostic factors
}

\author{
Imunoexpressão de biomarcadores do ciclo celular em amostras de neuroblastomas e sua \\ relação com fatores prognósticos
}

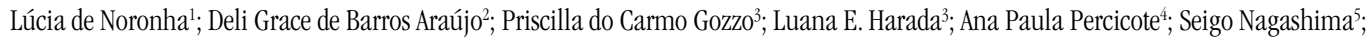
Elisabeth Schneider Gugelmin ${ }^{6}$; Flora Watanabe $;$ Milton Marcio Machota Junior ${ }^{8}$; Isabela Werneck da Cunha ${ }^{9}$

\begin{abstract}
Introduction: It is widely known that the expression levels of molecules involved in apoptosis regulation and cell proliferation have prognostic value in patients with neuroblastomas. Objective: To determine the expression of Ki67, B-cell lymphoma 2 (BCL-2), phosphatase and tensin homolog (PTEN), BCL-2 associated protein X (BAX) and caspase-8 proteins in neuroblastomas and to propose new prognostic biomarkers that could enable a better classification of risk groups. Material and methods: Formalin fixed paraffin embedded neuroblastoma samples $(n=$ 23) were arranged into tissue microarray blocks and analyzed by immunohistochemistry. The patients were classified according to clinical and pathological prognostic factors (age, site, presence or absence of bone-marrow infiltration, poorly or well differentiated ganglioneuroblastoma, Schwannian stroma rich or poor, favorable or unfavorable Shimada histology, and presence or absence of MYCN oncogene amplification) and clinical course (with or without fatal outcome, with or without relapses/residual lesion). Results: Twelve patients were female; nine children were over 18 months old; nine had extra-abdominal tumors; nine had tumors with unfavorable histology. Fifteen patients underwent bone-marrow biopsy and four were positive for metastasis. Nine patients progressed to fatal outcome. Conclusion: Ki67 immunoexpression was lower in cases of Schwannian-stroma rich neuroblastomas $(\phi=0.018)$ and higher in poorly differentiated cases $(\phi=0.013)$. PTEN was less positive in stroma rich neuroblastomas $(p=0.024)$. Caspase-8 was more immunopositive in cases of negative bone marrow infiltration $(p=0.035)$. Therefore, these biomarkers could be applied to discriminate groups with poor prognosis.
\end{abstract}

Key words: neuroblastoma; cell proliferation; apoptosis; prognostic factors.

\section{INTRODUCTION}

Neuroblastomas are embryonic neoplasias of the sympathetic nervous system. Besides, it is the most frequent extracranial solid tumor in infancy, commonly diagnosed among children younger than 12 months ${ }^{(14,18)}$.

Its behavioral diversity, which is sometimes characterized by aggressiveness, suggests that the malignant cell transformation is mostly due to a failure in the signaling pathways that regulate differentiation and cell proliferation ${ }^{(15)}$. In other occasions, neuroblastomas may present a relatively high benign differentiation rate with spontaneous regression, which may reflect an overactivity of cell differentiation programs and apoptotic cascades. It is particularly worth mentioning those cases with aggressive progression, with early relapses and unfavorable clinical course in spite of a good initial prognosis based on clinical pathological profile. The identification of these patients at diagnosis may allow the implementation of more aggressive therapeutic approaches, even though they are not justified by the initial favorable prognosis, which ultimately would optimize survival rates $(18,27,30)$.

First submission on 25/09/12; last submission on 16/12/12; accepted for publication on 26/12/12; published on 20/02/13

1. Doctor in Pathology by Universidade Federal do Paraná (UFPR); post graduation professor in Health Science at Pontifícia Universidade Católica Medical School (PUC-PR).

2. Doctor in Health Science by PUC-PR Medical School; pediatric oncologist.

3. Graduate student at PUC-PR Medical School.

4. Master in Pathology by UFPR; currently attending doctorate at UFPR Post Graduation Program in Microbiology, Parasitology and Pathology.

5. Biologist at PUC-PR Laboratory of Experimental Pathology.

6. Doctor in Pathology by UFPR; pathologist at Hospital Infantil Pequeno Príncipe-PR.

7. Master in Oncology; pediatric oncologist at Hospital Infantil Pequeno Príncipe-PR.

8. Specialist in Pathology by UFPR.

9. Doctor in Pathology; pathologist at Hospital A. C. Camargo-SP. 
The presence of high levels of proliferative proteins (Ki67) or apoptosis resistance proteins (B-cell lymphoma 2 [BCL-2]) and inhibition of pro-apoptotic proteins (phosphatase and tensin homolog [PTEN], BCL-2 associated protein X [BAX] and caspases) may explain the aggressive behavior of these tumors ${ }^{(14,40)}$ as well as their chemotherapy resistance ${ }^{(5)}$. It is acknowledged that the expression levels of molecules involved in apoptosis regulation and cell proliferation such as Ki67, PTEN, caspases, BCL-2 and BAX present prognostic value in patients with neuroblastomas ${ }^{(5,15)}$ By analyzing the tumorigenesis process of neuroblastoma and its mechanisms of cell proliferation and apoptosis resistance, we aim to evaluate proliferative and apoptotic biomarkers already reported by the literature (PTEN, Ki67, BAX, BCL-2 and caspase-8), whose immunohistochemical expression at diagnosis may be applied as a tool for the assessment of tumor aggressiveness. Accordingly, this may guide the therapeutic approach and improve its prognosis, which is quite particular ${ }^{(29)}$.

The objective of this study was to evaluate the immunohistochemical expression of proliferative and apoptotic biomarkers already reported by the literature (PTEN, Ki67, BAX, BCL2 and caspase-8) at the moment of diagnosis as a predictive tool for the assessment of tumor aggressiveness.

\section{MATERIAL AND METHODS}

The cases selected for this study comprised paraffin embedded samples of neuroblastomas from pediatric patients of both genders and without neoadjuvant chemotherapy $(n=23)$.

The cases were classified as follows: (a) child's gender; (b) age range at diagnosis ( $<18$ months or $\geq 18$ months); (c) lesion site at diagnosis (extra-abdominal or abdominal); (d) infiltrated or noninfiltrated bone marrow; (e) histological differentiation rate (poorly differentiated or in differentiation/ganglioneuroblastomas); (f) clinical course (fatal outcome or relapse/residual disease); (g) type of extracellular matrix (schwannian stroma rich or poor); (h) Shimada classification (favorable or unfavorable histology); (i) presence or absence of MYCN amplification in all cases.

Two tumor areas were prepared for tissue microarray blocks $(\text { TMA })^{(1)}$. Six sections were performed on the paraffin embedded TMA blocks ( $4 \mu \mathrm{m}$ thick) with primary antibodies and incubated for 12 hours in humid chamber at 2 to $8^{\circ} \mathrm{C}$. The following antibodies were applied: anti-PTEN Data Sheet (Novocastra ${ }^{\circledR}$ mouse monoclonal), antiKi67 (Dako ${ }^{\circledR}$ mouse monoclonal), anticaspase-8 (Dako ${ }^{\circledR}$ mouse monoclonal), antiBCL-2 (Dako ${ }^{\circledR}$ mouse monoclonal) and antiBAX (Dako ${ }^{\circledR}$ mouse monoclonal). Advance Dako ${ }^{\circledR}$ was used as a secondary antibody, which was incubated for 30 minutes at 2 to $8^{\circ} \mathrm{C}$. 3-3'diaminobenzidine complex (DAB) + Dako ${ }^{\circledR}$ substrate was added on electrically charged Star Frost ${ }^{\circledR}$ slides and counterstaining was carried out with Harris hematoxylin.

The slides immunostained with Ki67 and PTEN were analyzed through counting of positive nuclei per high power field (HPF) at optical microscopy (BX40 Olympus ${ }^{\circledR}$ microscope) with $40 \times$ objective. There were six HPF per case.
The slides immunostained with BCL-2, caspase- 8 and BAX were assessed through BX40 Olympus ${ }^{\circledR}$ microscope and Image Pro Plus ${ }^{\circledR}$ program with DELL ${ }^{\circledR}$ computer and Dino-eye ${ }^{\circledR}$ camera. The areas of immunopositivity for caspase-8, BCL-2 and BAX were identified with amplification of $400 \times$ HPF and image analysis software. The program determined the total immunopositive area in square micrometer $\left(\mathrm{um}^{2}\right)$ per HPF. Eight HPF were analyzed per case in order to establish the mean immunopositivity area per antibody (caspase-8, BCL-2 and BAX).

The assessment of MYCN amplification was undertaken through fluorescence in situ hybridization (FISH) at Hospital A. C. Camargo in São Paulo. We applied commercial probe (LSI SYT Dual Colour Break Apart Rearrangement Probe Vysis Abbott Laboratories UK) on electrically charged slides containing two micrometer TMA sections with neuroblastoma samples after deparaffinization, pre-treatment, heating and digestion with proteinase according to Vysis kit $^{(17)}$.

The statistical analysis considered data descriptive measures, including frequencies and percentages for categorical variables, mean, median, minimum values, maximum values and standard deviation for quantitative measures. Student's t test and non parametric MannWhitney test were used for comparison of groups defined by clinical pathological variables and clinical course in relation to quantitative variables. As to dichotomous nominal variables, the groups were compared through Fisher's exact test. The association level between two markers was calculated by Spearman's rank correlation coefficient and by Kappa coefficient. Kaplan-Meier curves were build to assess survival rates and comparison between curves was conducted by log-rank test. $p$ values $<0.05$ showed statistical significance. We employed SPSSV8 ${ }^{\circledR}$ statistical analysis program.

Receiver operating characteristic (ROC) curves were adjusted to determine the cut-off points that could best discriminate the relation between two histological groups (poorly differentiated and in differentiation/ganglioneuroblastoma). This determination enabled the separation of samples into two groups: (a) high immunopositivity; (b) low immunopositivity. Immunopositivity for Ki67 was considered high when there were more than 159 positive nuclei per HPF and low when there were less than 159 positive nuclei per HPF. Immunopositivity for PTEN was considered high when there were more than 637 positive nuclei per HPF and low for less than 637 positive nuclei per HPF.

\section{RESULTS}

There was no significant prevalence between male and female genders. Most patients were diagnosed with neuroblastoma with less than 18 months of age $(60.8 \%)$ and most lesions were abdominal (60.8\%) with well differentiated histological rate (60.8\%). Only $65 \%$ had undergone bone marrow biopsy and 26.6 of which had infiltrated bone marrow. At follow-up, three years after diagnosis $60 \%$ of patients were alive, though $57 \%$ still had the disease (Table 1)

Ki67 and PTEN immunoexpression was related to the type of tumoral stroma, noting that both biomarkers presented higher immunopositivity in stroma poor lesions $(p=0.018$ and $p=0.024$, respectively in the Table 1). 
TABLE 1 - Correlation between mean biomarker values per HPF and the studied clinical pathological variables

\begin{tabular}{|c|c|c|c|c|c|c|c|}
\hline Variable & & $n$ & Ki67 & PTEN & Caspase- 8 & BCL-2 & BAX \\
\hline \multirow{4}{*}{ Diagnosis } & Female & 12 & 188.78 & 475.49 & 41668619.83 & 4271.71 & 32939678.76 \\
\hline & Male & 11 & 183.76 & 649.58 & 37843054.17 & 5843.30 & 25279502.44 \\
\hline & $\leq 18$ months & 14 & 153.81 & 526.37 & 38878699.41 & 5005.19 & 30434898.82 \\
\hline & $>18$ months & 9 & 237.04 & 609.11 & 41332804.68 & 5133.07 & 27473565.38 \\
\hline \multirow[t]{2}{*}{ Site } & Extra-abdominal & 9 & 197.63 & 649.93 & 38850179.00 & 4996.59 & 24460117.90 \\
\hline & Abdominal & 14 & 179.14 & 500.13 & 40474673.06 & 5099.68 & 32372115.06 \\
\hline \multirow[t]{2}{*}{ Bone Marrow } & Negative & 11 & 189.15 & 524.29 & $41411751.7^{*}$ & 4882.30 & 32089747.91 \\
\hline & Positive & 4 & 205.17 & 563.83 & $41338283.5^{*}$ & 3921.56 & 36510520.00 \\
\hline \multirow[t]{2}{*}{ Differentiation } & Low & 9 & 276.00 & 724.74 & 39761505.47 & 5725.10 & 37807537.58 \\
\hline & High & 14 & 128.76 & 452.04 & 39888820.33 & 4595.33 & 23791630.98 \\
\hline \multirow[t]{2}{*}{ Shimada } & Favorable & 18 & 146.56 & 522.81 & 39096447.3 & 4882.79 & 26532881.30 \\
\hline & Unfavorable & 5 & 329.73 & 688.13 & 42512196.63 & 5651.56 & 39151761.70 \\
\hline \multirow[t]{2}{*}{ Stroma } & Poor & 9 & $276.00^{* *}$ & $724.74^{* * *}$ & 38518567.52 & 5139.15 & 42853898.15 \\
\hline & Rich & 14 & $128.76^{* *}$ & $452.04 * * * *$ & 39888820.33 & 4595.33 & 23791630.98 \\
\hline Deaths & Survival & 5.45 years & 192.96 & 685.11 & 43099546.44 & 4947.69 & 24848126.88 \\
\hline Alive & $\begin{array}{c}\text { Follow-up } \\
1.3 \text { years }\end{array}$ & 14 & 182.14 & 477.51 & 37742936.85 & 5133.53 & 32122680.72 \\
\hline $\begin{array}{l}\text { With relapse/ } \\
\text { residual }\end{array}$ & $\begin{array}{c}\text { Follow-up } \\
3 \text { years }\end{array}$ & 8 & 155 & 350.89 & 37161213.84 & 5128.72 & 24074267.64 \\
\hline $\begin{array}{l}\text { Without relapse/ } \\
\text { residual }\end{array}$ & $\begin{array}{c}\text { Follow-up } \\
3 \text { years }\end{array}$ & 6 & 218.33 & 646.32 & 38518567.52 & 5139.15 & 42853898.15 \\
\hline
\end{tabular}

As to BCL-2 and BAX, there were no statiscally significant differences between mean immunopositivity of these antibodies in comparison with groups defined by clinical pathological variables and clinical course. Caspase- 8 showed higher immunopositivity in cases with negative bone marrow in comparison with positive bone marrow $(p=0.035)$ (Table 1).

The cutoff points allowed new comparisons with groups defined by clinical pathological variables and clinical course (Tables 2, 3 and 4).

High immunopositivity for Ki67 protein $(p=0.013)$ demonstrated statiscally significant correlations with poorly differentiated neuroblastoma. The correlation between stroma pattern and ROC curves of Ki67 and PTEN was also evaluated. The high immunohistochemical expression of Ki67 (>159 positive nuclei per HPF) and PTEN ( $>637$ positive nuclei per HPF) was associated with Schwannian stroma poor cases $(p=0.012$ and $p=0,042$, respectively).

The correlation between BCL-2, BAX and caspase- 8 cutoff points and groups defined by clinical pathological variables and clinical course did not reveal statiscally significant results.

Following the clinical course analysis, there was no statistically significant correlation between fatal outcome/relapse rates and the surveyed biomarkers. There was a tendency to statistical significance in the correlation within low PTEN rates $(<637$ positive nuclei per $\mathrm{HPF}$ ) and high rates of post-chemotherapy residual disease $(p=0.070)$.

MYCN proto-oncogene amplification was conducted by FISH method and it was not observed in any of the cases from this study (Figure).

\section{DISCUSSION}

Most patients were diagnosed at less than 18 months old (60.86\%), which is commonly described in the literature. Although some authors claim there is a slight prevalence of the male gender (1.2 boys: 1 girl), there was no significant prevalence of gender in this study. It was observed a considerable percentage of cases with infiltrate bone marrow and extra-abdominal disease, that is to say, advanced clinical stages that aggravate the prognosis, as it is described in the literature ${ }^{(5)}$. Epidemiological data demonstrate that neuroblastomas present clinical pathological aspects that have a negative influence on the answer to the treatment, which increases the probability of chemoresistance and low survival rates. 
TABLE 2 - Correlation between Ki67 and the studied clinical pathological variables

\begin{tabular}{|c|c|c|c|c|}
\hline \multirow{2}{*}{ Variable } & \multicolumn{2}{|c|}{ Ki67 immunopositivity } & \multirow{2}{*}{ Total } & \multirow{2}{*}{$p$ value* } \\
\hline & $>159$ (high) & $\leq 159$ (low) & & \\
\hline \multicolumn{5}{|l|}{ Age at diagnosis } \\
\hline$\leq 18$ months & $5(35.71 \%)$ & $9(64.29 \%)$ & 14 & \\
\hline$>18$ months & $5(55.56 \%)$ & $4(44.44 \%)$ & 9 & 0.417 \\
\hline \multicolumn{5}{|l|}{ Lesion site } \\
\hline Extra-abdominal & $4(44.44 \%)$ & $5(55.56 \%)$ & 9 & \\
\hline Abdominal & $6(42.86 \%)$ & $8(57.14 \%)$ & 14 & 1.000 \\
\hline \multicolumn{5}{|l|}{ Bone marrow Status } \\
\hline Negative & $5(45.45 \%)$ & $6(54.55 \%)$ & 11 & \\
\hline Positive & $3(75.00 \%)$ & $1(25.00 \%)$ & 4 & 0.569 \\
\hline \multicolumn{5}{|l|}{ Shimada classification } \\
\hline Unfavorable & $4(80.00 \%)$ & $1(20.00 \%)$ & 5 & \\
\hline Favorable & $6(33.33 \%)$ & $12(66.67 \%)$ & 18 & 0.0886 \\
\hline \multicolumn{5}{|l|}{ Lesion differentiation } \\
\hline Poorly differentiated & $7(77.78 \%)$ & $2(22.22 \%)$ & 9 & \\
\hline Highly differentiated & $3(21.43 \%)$ & $11(78.57 \%)$ & 14 & 0.013 \\
\hline
\end{tabular}

Ki67 mean immunopositivity was assessed by the number of positive nuclei per HPF for each case.

*: Fisher's exact test, $\mathrm{p}<0.05$; HPF: high power field.

TABLE 3 - Correlation between PTEN biomarker and the studied clinical pathological variables

\begin{tabular}{|c|c|c|c|c|}
\hline \multirow{2}{*}{ Variable } & \multicolumn{2}{|c|}{ PTEN immunopositivity } & \multirow{2}{*}{ Total } & \multirow{2}{*}{$p$ value* } \\
\hline & $>637$ (high) & $\leq 637$ (low) & & \\
\hline \multicolumn{5}{|l|}{ Age at diagnosis } \\
\hline$\leq 18$ months & $5(35.71 \%)$ & $9(64.29 \%)$ & 14 & \\
\hline$>18$ months & $4(44.44 \%)$ & $5(55.56 \%)$ & 9 & 1.000 \\
\hline \multicolumn{5}{|l|}{ Lesion site } \\
\hline Extra-abdominal & $6(66.67 \%)$ & $3(33.33 \%)$ & 9 & \\
\hline Abdominal & $3(21.43 \%)$ & $11(78.57 \%)$ & 14 & 0.077 \\
\hline \multicolumn{5}{|l|}{ Bone marrow status } \\
\hline Negative & $4(36.36 \%)$ & $7(63.64 \%)$ & 11 & \\
\hline Positive & $1(25.00 \%)$ & $3(75.00 \%)$ & 4 & 1.000 \\
\hline \multicolumn{5}{|l|}{ Shimada Classification } \\
\hline Unfavorable & $3(60.00 \%)$ & $2(40.00 \%)$ & 5 & \\
\hline Favorable & $6(33.33 \%)$ & $12(66.67 \%)$ & 18 & 0.283 \\
\hline \multicolumn{5}{|l|}{ Lesion differentiation } \\
\hline Poorly differentiated & $6(66.67 \%)$ & $3(33.33 \%)$ & 9 & \\
\hline Highly differentiated & $03(21.43 \%)$ & $11(78.57 \%)$ & 14 & 0.077 \\
\hline
\end{tabular}

PTEN mean immunopositivity was assessed by the number of positive nuclei per HPF for each case.

*: Fisher's exact test, $\mathrm{p}<0.05$; PTEN: phosphatase and tensin homolog; HPF: bigh power field.

TABLE 4 - Correlation between the neoplasia stroma pattern (Schwannian stroma rich or poor) and Ki67 and PTEN ROC curves calculated by exact Fisher test

\begin{tabular}{ccc}
\hline & $p$ value & Hypothesis \\
\hline Ki67 Fisher's exact test & 0.012 & Stroma rich cases may have low Ki67 values and stroma poor cases may have high Ki67 values \\
PTEN Fisher's exact test & 0.042 & Stroma rich cases may have low PTEN values and stroma poor cases may have high PTEN values \\
\hline
\end{tabular}

ROC: receiver operating characteristic; PTEN: phosphatase and tensin homolog. 


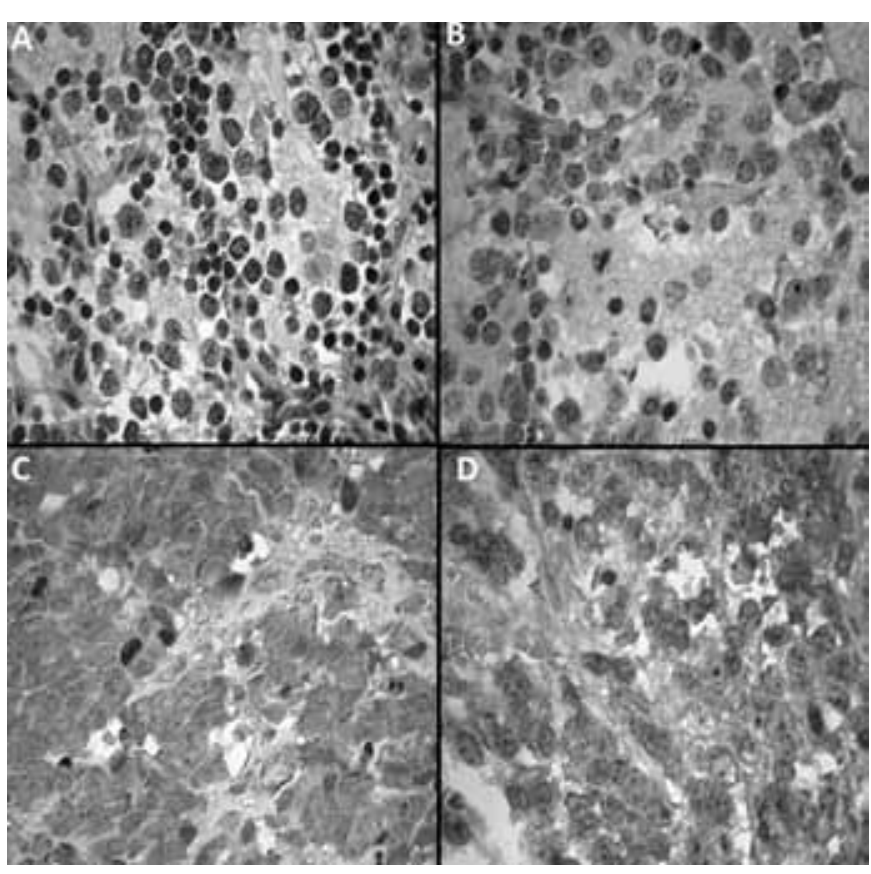

FIGURE - Immunopositivity of neuroblastoma biomarkers. A) PTEN: nuclear positivity; B) BCL-2: perinuclear positivity; C) caspase-8: cytoplasmic positivity; D) BAX: cytoplasmic positivity. 400x

PTEN: phosphatase and tensin homolog; BCL-2: B-cell lymphoma 2; BAX: BCL-2 associated protein $X$. association between high rates of the marker and tumors classified as undifferentiated, which evinces an increase in the proliferative index in cases with poor prognosis ${ }^{(11,17)}$. Several authors claim that this marker is a relevant proliferative index and it can be incorporated into the diagnostic routine of several tumors to evince tumoral aggressiveness despite the fact it cannot be considered a prognostic predictor solely $(8,16,17,36,41)$. As it is corroborated by other researchers, in our study the high expression rates of this protein were statiscally related to tumors with unfavorable histology. Ki67 may be a marker of low differentiation and poor clinical evolution in neuroblastomas, which aids the stratification of more aggressive tumors.

PTEN was another surveyed marker. Its high rate was observed in patients with extra-abdominal lesions and with low differentiated tumors, demonstrating a statistical tendency in these cases. Furthermore, PTEN immunohistochemical expression rates were higher in cases with stroma- poor, which would have poor prognosis. These findings seem to be contrary to those observed by other studies, in which high PTEN expression rates were generally linked with good prognostic factors ${ }^{(3,16)}$, inasmuch as PTEN is a tumor suppressor gene. Nevertheless, the changes in its signaling pathways (mainly phosphatidylinositide 3-kinases [PI3-K]) would cause a modification in the normal cell apoptosis pathway.

PTEN also seems to operate as cell cycle controller by avoiding excessive proliferation ${ }^{(30,33,39,42)}$. Low PTEN expression commonly leads to an unbalance in the cell regulation function and, therefore, a worse progression, which is evinced in tumors such as glioblastomas and pancreas carcinomas, apart from neuroblastomas ${ }^{(10,13,22,30,38,39)}$. The fact that we had higher PTEN immunohistochemical expression in stroma-poor cases (poor prognosis according to Shimada) could represent solely an epiphenomenon, that is to say, PTEN protein expression would be high since the proliferation rates of these tumors would be much higher and PTEN would operate as cell cycle regulation and apoptosis inductor, inasmuch as undifferentiation promotes proliferation and apoptosis. As neuroblastomas differentiate, both proliferation and apoptosis rates tend to reduce as well as PTEN expression. It is widely acknowledged in the literature that poorly differentiated neuroblastomas have high apoptosis rates (represented by high mitosis/karyorrhexis indexes). The latter would be a criterion proposed by Shimada for the classification of these tumors into favorable and unfavorable histology. Moreover, PTEN marker exhibited a tendency to correlation with residual disease, considering that the cases with low PTEN immunopositivity presented high rates of post-chemotherapy residual disease $(p=0.070)$, which corroborates the hypothesis that low PTEN immunoexpression may represent a poor response to the treatment.

BCL-2 gene family, namely pro-apoptotic (BAX) and anti-apoptotic (BCL-2) molecules, play a crucial role in apoptosis regulation, insofar as they directly activate caspase pathways ${ }^{(4,6,9,12,23,24,26,28)}$. The analysis of these markers in the selected neuroblastoma samples revealed no statistically significant correlation neither among them, nor among the studied clinical and pathological variables. Subramaian et al. ${ }^{(34)}$ noted that drugs that activate BAX expression provided a better cytotoxic response in neuroblastomas and ganglioneuromas. Chesler et al. investigated the relation between chemoresistance and BCL-2 and BAX 
expression in neuroblastomas and high BCL-2 rates were linked with high chemotherapy resistance rates ${ }^{(7,19)}$.

As to caspases, in our study there was no statiscally significant correlation when we compared immunohistochemical caspase- 8 results with clinical pathological variables, except when we analyzed caspase- 8 immunopositivity with cases in which there was no bone marrow infiltration. The expression of this marker was higher in these samples. Caspases are widely acknowledged by its importance in programmed cell death and several studies correlate caspase inhibition, mainly caspase-8, with neoplasias such as adenocarcinomas, pulmonary carcinomas and neuroblastomas ${ }^{(21,25,31,35)}$. Caspase- 8 is a pro-apoptotic protease and in neuroblastomas it would induce programmed cell death, hence its relation with better prognosis, as it was substantiated in our study. Nevertheless, this protein also promotes the migration of non-apoptotic cells and may contribute to metastases when apoptosis is impaired. Caspase- 8 interacts with multi-protein complexes that include focal adhesion kinase (FAK) and calpain 2 (CPN2), it increases cleavage of FAK substrates and it also promotes cell migration. The absence of caspase- 8 expression may be linked with chemotherapy resistance ${ }^{(2,20,31,32)}$. Thus, in our study this protein was associated with patients with better prognosis, which is also corroborated by the literature.

\section{CONCLUSION}

Ki67 immunopositivity revealed statiscally significant correlation with stroma- rich neuroblastomas, considering that it was less positive in these cases $(p=0.018)$. Furthermore, it also showed high immunopositivity in cases with poorly differentiated and stroma- poor neuroblastomas ( $\phi=0.013$ e 0.012 , respectively).

PTEN positivity exhibited statiscally significant correlation with stroma- rich neuroblastomas and it was less positive in these cases $(p=$ 0.024). Its high immunopositivity was more frequent in stroma- poor cases $(p=0.042)$.

Caspase- 8 was more positive in patients with negative bone marrow.

The authors believe that these biomarkers could be employed to aid the identification of those patients that, in spite of belonging to low risk groups, may progress to a worse prognosis.

\section{RESUMO}

Introdução: Sabe-se que os niveis de expressão de moléculas envolvidas na regulação da apoptose e da proliferação celular apresentam valor prognóstico em pacientes com neuroblastomas. Objetivo: Avaliar a imunoexpressão das proteínas Ki67, B-cell lymphoma 2 (BCL2), phosphatase and tensin homolog (PTEN), caspase-8 e BCL-2 associated protein X (BAX) em neuroblastomas na tentativa de propor novos biomarcadores prognósticos que poderiam auxiliar na melhor discriminação dos grupos de risco. Material e métodos: Amostras de neuroblastoma $(\mathrm{n}=23)$ foram submetidas à técnica tissue microarray e analisadas com imuno-bistoquímica. Os pacientes foram classificados de acordo com os fatores prognósticos clínico-patológicos (idade, localização, medula óssea infiltrada ou não, pouco diferenciado ou em diferenciação/ganglioneuroblastoma, rico ou pobre em estroma com células de Schwann, histologia favorável ou desfavorável segundo Shimada, presença ou não da amplificação do MYCN) e com o curso clínico (se em óbito ou vivo, com ou sem lesão residual/recidiva). Resultados: Doze casos eram do sexo feminino; nove tinham idade acima de 18 meses; nove apresentavam tumores extra-abdominais; e nove cursavam com histologia desfavorável. Quinze pacientes foram submetidos à biópsia de medula óssea, sendo quatro com apresentação de metástase. Nove pacientes evoluíram ao óbito. Conclusão: A imunoexpressão do Ki67 foi mais baixa nos casos ricos em estroma $(\mathrm{p}=0,018)$ e elevada nos casos pouco diferenciados $(\mathrm{p}=0,013)$. O PTEN apresentou-se menos positivo em neuroblastomas ricos em estroma $(\mathrm{p}=0,024)$. A caspase-8 foi mais imunopositiva em casos com medula óssea negativa $(\mathrm{p}=0,035)$. Esses biomarcadores poderiam ser utilizados para auxiliar a discriminar grupos de pacientes de pior prognóstico.

Unitermos: neuroblastoma; proliferação celular; apoptose; fatores prognósticos.

\section{REFERENCES}

1. ANDRADE, V. P. et al. 0 arranjo em matriz de amostras teciduais (tissue microarray): larga escala e baixo custo ao alcance do patologista. J Bras Patol Med Lab, v. 43, n. 1, p. 55-60, 2007.

2. BARBERO, S. et al. Caspase 8 association with the focal adhesion complex promoter tumor cell migration and metastases. Cancer Res, v. 69, n. 9 , p. 3755-63, 2009.
3. BLANCO-APARICIO, C. et al. PTEN, more than the AKT pathway. Carcinogenesis, v. 28, n. 7, p. 1379-86, 2007.

4. BRAMBILLA, E. et al. Apoptosis-related factors p53, Bcl2, and Bax in neuroendocrine lung tumors. $A J P$, v. 149, n. 6, p. 1941-52, 1996.

5. CASCIANO, I. et al. Caspase 8 gene expression in neuroblastoma. Ann NY Acad Sci, v. 1028, p. 157-67, 2004.

6. CHAN, H. W. et al. Copper induces apoptosis of neuroblastoma cells via post-translational regulation of the expression of BcL2-family proteins and 
the tx $\mathrm{X}^{\mathrm{J}}$ mouse is a better model of hepatic than brain Cu toxicity. Int J Clin Exp Med, v. 1, n. 1, 76-88, 2008.

7. CHESLER, L. et al. Chemotherapy - induced apoptosis in a transgenic model of neuroblastoma proceeds through $\mathrm{p} 53$ induction. Neoplasia, v. 10, n. 11, p. 1268-74, 2008.

8. DOESETT, M. et al. Who would have thought a single Ki67 measurement would predict long-term outcome? Breast Cancer Res, Suppl. 3, p. S15, 2009.

9. FANG, J. et al. Tissue factor/FVIIa activater Bcl2 and prevents doxorubicininduced apoptosis in neuroblastoma cells. BMC Cancer, v. 8, n. 69, p. 1-11, 2008

10. FRASER, M. M. et al. Pten deficiency in brain causes defects in synaptic structure, transmission and plasticity, and myelination abnormalities. Neuroscience, v. 151, n. 2, p. 476-88, 2008.

11. GRAHAN, D. et al. Evaluation of Ki67 reactivity in neuroblastoma using paraffin embedded tissue. Pathol Res Pract, v. 191, n. 2, p. 87-91, 1995.

12. GHATAN, S. et al. P38 MAP kinase mediater Bax translocation in nitric oxide-induced apoptosis.J Cell Biol, v. 150, n. 2, p. 335-47, 2000.

13. HOLLANDER, M. C. et al. Strain-specific spontaneous and NNK-mediated tumorigenesis in Pten+/-Mice. Neoplasia, v. 10, n. 8, p. 866-72, 2008.

14. HOPKINS-DONALDSON, S. et al. Loss of caspase 8 expression in highly malignant human neuroblastoma cells correlates with resistance to tumor necrosis factor-related apoptosis-inducing ligand-induced apoptosis. Cancer Res, v. 60, n. 16, p. 4315-9, 2000.

15. ISLAM, A. et al. High expression of survivin, mapped to $17 \mathrm{q} 25$, is significantly associated with poor prognostic factors and promotes cell survival in human neuroblastoma. Oncogene, v. 19, n. 5, p. 617-23, 2000.

16. KIM, D. K. et al. Ki67 antigen as a predictive factor for prognosis of sinonasal mucosal melanoma. Clin Exp Otorbinolaryngol, v. 1, n. 4, p. 206-10, 2008.

17. KORJA, M. et al. Chromogenic in situ hybridization detected hotspot MYCN amplification associates with Ki67 expression and inversely with nestin expression in neuroblastomas. Mod Pathol, v. 18, n. 12, p. 1599-605, 2005.

18. KUSHNER, B. H.; CHEUNGK, N. V. Neuroblastoma - from genetic profiles to clinical challenge. $N$ Engl J Med, v. 353, n. 21, p. 2215-17, 2005.

19. LAI, J. P.; DALTME, J. T.; KNOELL, D. L. Phosphatase and tensin homologue deleted on chromosome ten (PTEN) as a molecular target in lung epithelial wound repair. Br J Pharmacol, v. 152, n. 8, p. 1172-84, 2007.

20. LI, C. L. et al. Regulation of apoptosis and caspase 8 expression in neuroblastoma cells by isoforms of the IG20 Gene. Cancer Res, v. 68, n. 18, 7352-61, 2008.

21. LOUCKS, F. A. et al. Caspases indirectly regulate cleavage of the mithocondrial fusion GTPase OPA1 in neurons undergoing apoptosis. Brain Res, v. 1250, p. 63-74, 2009.

22. MACCARIO, H. et al. PTEN is destabilized by phosphorylation on Thr ${ }^{366}$. Biochem J, v. 405, p. 439-44, 2007.

23. MACFARLENE, M.; WILLIAMS, A. C. Apoptosis and disease: a life or death decision. EMBO reports, v. 5, n. 7, p. 674-78, 2004.

24. MAKIN, G. W. J. et al. Damage - induce Bax N-terminal change, translocation to mitochondria and formation of Bax dimmers/complexes occur regardless of cell fate. EMBO J, v. 20, n. 22, p. 6306-15, 2001.

25. MAZUNDER, S.; ALMASAN, A. Is caspase 8 a neuroendocrine lung tumor suppressor? Cancer Biol Ther, v. 1, n. 1, p. 70-1, 2002.
26. MIRESKANDARI, M. et al. Lack of CD 117 and rare Bcl2 expression in stomach cancer by immunohistochemistry. An immunohistochemical study with review of the literature. Diagn Pathol, v. 1, n. 7, p. 1-8, 2006.

27. OUE, T. et al. In situ detection of DNA fragmentation and expression of Bcl2 in human neuroblastoma: relation to apoptosis and spontaneous regression.J Pediatr Surg, v. 31, n. 2, p. 251-7,1996.

28. PARIKH, N. et al. The N-terminus and alpha-5, alpha-6 helices of the pro-apoptotic protein Bax, modulate functional interactions with the antiapoptotic protein Bcl-XL. BMC Cell Biology, v. 8, n. 16, p. 1-16, 2007.

29. PERONA, R.; SÁNCHEZ-PÉREZ, I. Control of oncogenesis and cancer therapy resistance. Br J Cancer, v. 90, n. 3, p. 573-7, 2004.

30. QIA0, J. et al. Gastrin-releasing peptide-induced down-regulation of tumor suppressor protein PTEN (phosphatase and tensin homolog deleted on chromosome ten) in neuroblastomas. Ann Surgery, v. 241, n. 5, p. 68492, 2005.

31. RAGUÉNEZ, G. et al. Fenretinide-induced caspase 8 activation and apoptosis in an established model of metastatic neuroblastoma. BMC Cancer, v. 9 , n. 97, p. 1-13, 2009.

32. ROGERS, D. et al. Molecular predictors of human nervous system cancer responsiveness to enediyne chemotherapy. Cancer Chemother Pharmacol, v. 62 , n. 4, p. 699-706, 2008.

33. SAAL, L. H. et al. Poor prognosis in carcinoma is associated with a gene expression signature of aberrant PTEN tumor suppressor pathway activity Proc Natl Acad Sci USA, v. 104, n. 18, p. 7564-9, 2007.

34. SUBRAMAIAN, C. et al. CREB - binding protein via mediator of neuroblastoma cell death induced by the histone deacetylase inhibitor trichostatin A ${ }^{1}$. Neoplasia, v. 9, n. 6, p. 495-503, 2007.

35. TERZIAN, A. C. B. et al. Avaliação da caspase-3 e Ki67 como marcadores prognósticos nas neoplasias mamárias em cadelas. Braz J vet Res anim Sci, v. 44, n. 2, p. 96-102, 2007.

36. TISSEL, L. E. et al. The Ki67 index a prognostic marker in medullary thyroid carcinoma. Br J Cancer, v. 89, n. 11, p. 2093-97, 2003

37. VIEIRA, F. L. D. et al. Cellular profile of the peritumoral inflammatory infiltrate in squamous cells carcinoma of oral mucosa: correlation with the expression of Ki67 and histologic grading. BMC Oral Health, v. 8, n. 25, p. 1-8, 2008

38. WEN, S. et al. PTEN controls tumor-induced angiogenesis. Proc Natl Acad Sci USA, v. 98, n. 8, p. 4622-7, 2001.

39. WESTPHAL, S.; KALTHOFF, H. Apoptosis: targets in pancreatic cancer. Mol Cancer, v. 2, p. 6, 2003.

40. WITTKE, I. et al. Neuroblastoma-derived sulfhydryl oxidase, a new member of the sulfhydryl oxidase/quiescin6 family, regulates sensitization to interferon gamma-induced cell death in human neuroblastoma cells. Cancer Res, v. 63, n. 22, p. 7742-52, 2003.

41.ZHENG, Y. et al. Expression of p53, c-erbB and Ki67 in intestinal metaplasia and gastric carcinoma. World J Gastroenterol, v. 16, n. 3, p. 339-44, 2010.

42. ZHOU, Y. et al. Modeling prognosis for patients with malignant astrocytic gliomas: quantifying the expression of multiple genetic markers and clinical variables. Neuro Oncol, v. 7, n. 4, p. 485-95, 2005.

\section{MAILING ADDRESS}

\section{Lucia de Noronha}

Escola de Medicina; Pontifícia Universidade Católica do Paraná; Rua Imaculada Conceição, 1155 - Prado Velho; CEP: 80215-901 - Curitiba-PR, Brazil; e-mail:Inno@terra.com.br. 